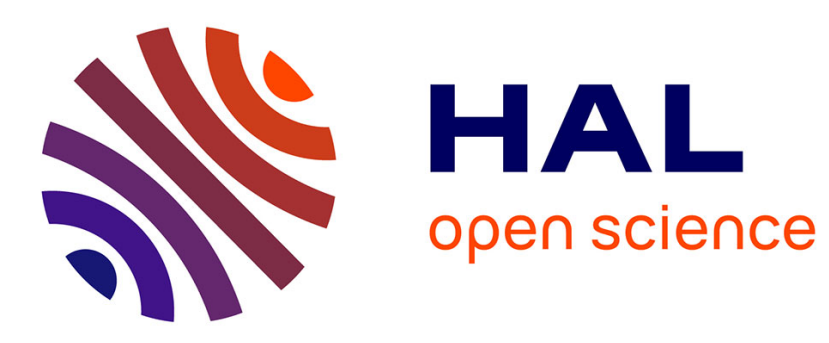

\title{
Creativity Filter and Start-Ups to Resolve the Innovation Paradox
}

David Audretsch, Maksim Belitski

\section{To cite this version:}

David Audretsch, Maksim Belitski. Creativity Filter and Start-Ups to Resolve the Innovation Paradox. 16th International Conference on Informatics and Semiotics in Organisations (ICISO), Mar 2015, Toulouse, France. pp.195-203, 10.1007/978-3-319-16274-4_20 . hal-01324978

\section{HAL Id: hal-01324978 \\ https://inria.hal.science/hal-01324978}

Submitted on 1 Jun 2016

HAL is a multi-disciplinary open access archive for the deposit and dissemination of scientific research documents, whether they are published or not. The documents may come from teaching and research institutions in France or abroad, or from public or private research centers.
L'archive ouverte pluridisciplinaire HAL, est destinée au dépôt et à la diffusion de documents scientifiques de niveau recherche, publiés ou non, émanant des établissements d'enseignement et de recherche français ou étrangers, des laboratoires publics ou privés.

\section{(c)(1)}

Distributed under a Creative Commons Attribution| 4.0 International License 


\title{
Creativity Filter and Start-ups to Resolve the Innovation Paradox
}

\author{
David Audretsch ${ }^{1}$, Maksim Belitski ${ }^{2}$ \\ ${ }^{1}$ Institute for Development Strategies, Indiana University Bloomington \\ 1315 E. 10th Avenue SPEA Bloomington, IN 47405, USA \\ ${ }^{2}$ Henley Business School, University of Reading \\ Whiteknights, Reading, RG6 6UD, United Kingdom. \\ daudrets@indiana.edu, m.belitski@reading.ac.uk
}

\begin{abstract}
The literature on creativity and innovation traditionally focuses on how individuals and R\&D teams generate and implement novel ideas and search for opportunities. It also highlights the role of skills, motivation and knowledge as a source of opportunities and innovation. As the gains from skills and knowledge are uncertain, the degree of creativity spillover could be an important consideration. To address this gap in the literature we examine the role of the creativity filter in the relationship between knowledge and innovation in the organization.
\end{abstract}

Keywords: Creativity filter $\cdot$ innovation $\cdot$ knowledge management $\cdot$ skills $\cdot$ inter-organization.

\section{Introduction}

There is an increasing interest in understanding how opportunities and new ideas are created [2], [3]. Firms need new ideas that expand their market share and bring new products [22]. One of the key focus of entrepreneurship is understanding why some firms are better than others to identify opportunities and bring new ideas [3] and why employment of high level skills and knowledge may not result in greater innovation, known as an "Innovation paradox" [17]. While there is a disagreement in the management and innovation literature about the process of creating innovation [1], the central components of opportunities are knowledge, motivation and skills [15], [6], [17]. Fostering skills and knowledge that help to create new opportunities [18], has become the priority for new entrepreneurial firms. New entrepreneurial firms have greater abilities to innovate than established mature firms, as new entrepreneur's ability to identify opportunities is related to knowledge [3], experience and skills. Employment of people within certain functional areas (design, software, and engineering) helps firms to shape knowledge and innovate [14].

Despite extensive theorizing about the importance of various external factors as predictors of new ideas and economic performance, that include education and competences [15]; team creativity and leadership [12]; cognitive styles of creativity [16], [17] extant empirical research misses the link between available knowledge and skills,

adfa, p. 1, 2011.

(C) Springer-Verlag Berlin Heidelberg 2011 
knowledge management and innovation outcomes [7]. In understanding this link scholars have integrated goal orientation theory [13], the knowledge spillover of entrepreneurship theory [3], [4], organizational creativity theory [2], [14] social capital theory [24] and social information processing and exchange theory [12], [17].

Despite all of this knowledge, above theories have not examined availability the role of knowledge management and organizational factors that enable knowledge and skills transformation into new ideas and performance [20], [21].

In this study, knowledge is seen as availability of skills within the company or purchase external skills (e.g. design and graphics, multimedia and software, and engineering and math skills) and human capital that includes both the formal education as well as tacit knowledge from experience and practical learning. Following prior studies [3], [4], [5], we expect that knowledge promotes innovation and economic efficiency. Motivation through a broad range of organizational and inter-organizational practices aiming in developing creativity within the organization and innovative orientation of a firm is likely to moderate the relationship between knowledge and innovation [12]. We aim to understand how characteristics of a firm, in particular skills and education effect innovation of a focal firm. What is the role of knowledge management and firm-specific internal characteristics (further - creativity filter) in the relationship of knowledge management and commercialisation?

This study makes a discussion and contributes into open innovation and creativity literature by unpacking the role of creativity as a filter of knowledge to innovation [1], [8]. We take a firm level perspective, exploring firm-level characteristics as a conduit of knowledge to innovation.

\section{Knowledge, Creativity and Innovation}

Knowledge and skills are the building blocks of creativity [2] and are important to the ability to innovate [8]. They allow firms to deviate from their counterparts and come up with breakthroughs that may change methods of production and processing while promoting the acceptance of innovation. By generating novel ideas that require new solutions, workers with creative skills and knowledge [10] provide their companies with new knowledge that brings new marketable opportunities [5]. The most direct link is reflected in the commercialization of knowledge through the creation of a new business. This relationship lies at the heart of the 'knowledge spillover theory of entrepreneurship' [4]. The combination of skills and ideas is not static, and may respond to changes in the firms organizational and innovation climate. Employing creative individuals and encouraging the expression of their voices increases the likelihood of identifying problems and generating new ideas [14], triggering new ways of thinking and modes of [17]. Traditional measurement of knowledge by the human capital or occupations [10] was found to be correlated with a range of other indicators capturing the formal qualifications of the workforce. Hence it was unclear whether the knowledge captures only education or more generic skills and experiences. We use a combination of skills and a proportion of workforce with scientific degrees as measure knowledge at a firm-level. Both skills and workforce qualification enable firms to change the way opportunities are defined, and be a source of these opportunities to increase innovation [7], [1] we assume: 
Proposition 1. Firms that deploy skills and employ workforce with scientific degrees are likely to have higher level of innovation.

\section{The Innovation Paradox and The Creativity Filter}

Despite the importance of skills and formal education for generating new ideas previous management literature has found a neutral or even negative outcomes related to idea implementation [16]Although firms may employ individuals within certain functional areas with the personal attributes associated with idea generation (e.g., creativity) [2] it is unclear whether these ideas and experiences will become innovation. This finding is not surprising given innovation requires out-of-the-box thinking, exploration, risk-taking and tolerance of mistakes. It requires promoting knowledge through firm organizational and managerial practices and channels, creating a conducive environment for innovation in organization [25]. Thus, if the above conditions do not hold successful implementation of ideas becomes questionable [26]. This contradiction inherent in innovation was called "The innovation paradox."

We know that workers often complain that their firms are reluctant to introduce change, and that they find it difficult to work within the existing firm strategy and practices, and so that these practices may impede new ideas to sprout out [17], [8]. Deploying variety of skills (e.g. IT, multimedia, design, math, engineering, graphics, etc.) within certain functional areas may not result in higher level of innovation, as positive effect of some companies will be cancelled out by the negative effects. Workers with skills are subjected to inter-organizational environment and factors that are there to motivate workers and enhance not "enforce" the implementation of new ideas [5]

Social information processing theory [12] and knowledge spillover of entrepreneurship theory [4] could be used to further describe the process linking knowledge, creativity and innovation.

Within the social information perspective, firms acquiring creative for their innovation create certain types of behaviors and performance that gives rise to an environment supportive of creativity [26]. It also conveys expectations of creative performance within the firm. Empirical studies found this dimension is the only significant predictor of innovation novelty [26], as workers may or may not agree to share their idea should the benefits of doing so be uncertain and the working environment hazardous for creativity [20], [21]. A complex of organizational and inter-organizational practices work as a creative environment, which enables more efficient conversion of knowledge into innovation. This mechanism describing the link between knowledge and innovation may be described a creativity and work as a filter to knowledge. The creativity filter is a high-level umbrella construct that captures the impeding or moderating effects of a broad range of organizational as well as inter-organizational mechanisms that may hamper innovation and innovative orientation by a firm through investment in in-house R\&D and other creative expenses to support innovation inhouse. According to the social information processing theory, creativity will moderate the power of knowledge. Unlike the knowledge filter, described [4, 12, 47] as, "the inertia inherent in decision-making under uncertainty within incumbent organiza- 
tions", the "creativity filter" refers to enforcement of organizational and interorganizational mechanisms and R\&D intensity that moderate or hamper innovation [5]. These practices and innovation inputs pose significant constraints on the behavior of employees [25]. First, we expect more creative behavior to evolve through the new organizational and inter-organizational mechanisms (e.g. systems of employee responsibilities, teamwork, de-centralization, integration or de-integration of work, and training) when individuals can access and implement new ideas, perspectives, and knowledge. Second, the employee's creative behavior will be supported by an information exchange with external firms or public institutions (e.g. alliances, partnerships, outsourcing or sub-contracting), provides a platform through which innovation can diffuse. Both activities make up an organizational component of the filter. Another R\&D component of the filter represents creative expenditure that improves innovation [23] exposes workers to diverse ideas both internally and through external interactions

The creativity filter will enforce a higher flow of knowledge and deployment of skills through promoting responsibilities, teamwork, integration, and information exchange resulting in more ideas to sprout-out [9].

Proposition 2. The creativity filter moderates the relationship between the knowledge and innovation.

\section{Creativity and new entrepreneurial firms}

The mechanism of commercialization of knowledge and ideas is new entrepreneurial start-up described in the 'knowledge spillover theory of entrepreneurship' [2]. Since knowledge tends to be 'sticky' in space, it becomes a determinant of entrepreneurial start-ups.

Drawing on the knowledge spillover theory of entrepreneurship and its human capital component [1] we posit that knowledge needs to be enhanced by someone, whether an individual or a company, who can take a responsibility of ideas and deliver innovation to the market. Starting an entrepreneurial venture spillovers knowledge which otherwise would remain un-commercialized [5]. New entrepreneurial firms are more successful than their old counterparts in enhancing innovation.

Along with the creativity filter, young businesses are better in resolving the "Innovation paradox" by outperforming their market counterparts through creative destruction. Next we consider the time period for knowledge spillovers. We assume up to three year time lag is a sufficient period for any specific information on development decisions, R\&D, and new ideas to spread in the market and across all sectors. The speed of information spread and commercialization of a product could be higher for other sectors, such as IT and engineering. We suggest start-ups serve as a conduit of new ideas and as a creativity filter per se which filters out good ideas resulting in start-ups.

Although new firms moderate the relationship between skills and innovation, the same role could also be performed by existing and more experienced firms operating in innovative fields, like knowledge-based companies (ICT, bioengineering, pharma- 
ceutics). Such firms typically hire highly educated and skilled individuals (engineers, telecommunications graduates) to implement and further develop new ideas and innovations (e.g., Sony, Apple or Microsoft). In measuring the moderation role of both start-ups and established firms, we need to take into account several possible channels of creativity to the market which allows us not to overstate the relevance of any specific type of a conduit.

Proposition 3. New entrepreneurial firms moderate the relationship between the knowledge and innovation.

\section{$5 \quad$ Measures and approach}

Innovation is measured as the percentage of a business's total turnover from goods and services that were new to the market [26]. In line with the management and economics literature $[1,4,5]$. Productivity could bhe reflected by two measures. The first measure consists of the gross value added in sales. The second measure consists of the wages and other employment benefits paid to firm's sales.

Our variables of interest are creativity and the creative environment which can either enhance or constrain the creativity. Building on what is needed for individual creativity [11], we follow $[1,20,21]$ in operationalizing a firm's creativity in terms of the employment of individuals with skill at any level in the graphic arts/layout/advertising and design of objects, multimedia/web design, software/database development and management, or engineering/applied sciences and mathematics/statistics. Firms may also obtain these skills from external sources for in-house use. Usually a binary answer is obtained for each of the three types of creative skills ( 0 means skills were not employed, and 1 means skills were employed).

We draw on [26], who originally developed the scale measuring the creative climate supportive for innovation along with [8], [11]. The mechanism describing the link between creativity and innovation may work as a filter to knowledge and therefore termed a creativity filter.

The creativity filter is a composite indicator of complex organizational systems. It consists of an organizational and innovation input (R\&D) component. To be able to design and develop the creativity filter researchers jointly with the Office of national Statistics, UK have conducted phone interviews. In the sample 155 R\&D managers located in various UK regions representing the manufacturing, service and R\&D sectors. 130 responses were interviewed. The results were used to assign appropriate weights to organization component of the filter - introduced by three organizational and business practices (see formula 1 below).

$$
F_{i}=\left(w_{0.25} M_{1 i}+w_{0.5} M_{2 i}+w_{0.25} M_{3 i}\right)+R D_{i}
$$

$F_{i}$ is the size of the filter of a firm $i$ in industry $j$. The R\&D effort - innovation component of the filter is given as the choice of a firm to invest in in-house creative work undertaken within the business that increases knowledge. This can be for the purpose of developing new and improved products and processes for current or future 
innovation. The R\&D component contributes half of the filter size, which varies between zero - no R\&D expenditure - and one - in-house R\&D expenditure is undertaken.

The organizational part of the filter is a composite sum of the three types of organizational strategies and practices applied by organization. It aims at raising internal efficiency and the effectiveness of approaching markets and customers. The higher the score, the smaller the size of the creativity filter and the smaller the gap between commercialized and un-commercialized creativity.

Companies that have fewer than 10 employees, have not introduced at least one method of organizing work and business practices over the period of 2008-2010 and companies that did not provide any rank of those practices were excluded. Respondents were asked to rank organizational and business practices by their importance to innovation. Most respondents (102) placed $M_{2 i}$, referring to new methods of organizing work responsibilities and decision making (i.e. the first use of a new system of employee responsibilities, teamwork, de-centralization, the integration or deintegration of departments, education/training systems, etc.) as the most relevant component of organizational innovation. More than half of the respondents (70) ranked $M_{1 i}$ as the first or second most important component of innovation, which refers to new business organizing procedures (i.e. supply chain management, business re-engineering, knowledge management, lean production, quality management, etc.) and constitutes a quarter of the organizational component of the filter. Finally, the rest of the group ranked $M_{3 i}$ as the second or third most important component of innovation, which refers to new methods of organizing an organization's external relationships with other firms or public institutions (i.e. the first use of alliances, partnerships, outsourcing or sub-contracting etc.).

We distributed the weights equally between $M_{2 i}$ and $M_{3 i}$ by assigning 0.25 of the unity of the organizational components that contribute half of the filter size. This varies between zero (no organizational strategy or practices were introduced) and one (all three types were introduced). The interview method was used in order to shed more light on the relevance of each specific organizational practice to the process of introducing new products to the market. This meant we could be flexible and precise when distributing the weights, rather than treating all new practices as equally important. The organizational and innovation components of the filter vary between zero and two.

In order to test the moderating effects of the filter in linking the process of creativity and knowledge flow to innovation we included the interaction of each type of creative skill in the model. As control variables we will need to include firm size (log of the number of employees and the square of the log of number of employees), UK regions, sector dummy, an exporting dummy, the effectiveness of patent protection $(0$ : patent protection not used to 3 : high efficacy), enterprise age. 


\section{Managerial Implications}

The model demonstrates firm's reliance on availability of skilled and creative employees both inside and outside a firm. Business start-ups and experienced established companies exploring new opportunities is an important factor shaping creativity into marketable products and processes. On the one hand, establishing a new business is the most efficient and quick way to commercialize creative skills. On the other hand, start-ups are on average less productive than established firms, unless they are successful in employment of individuals with a mix of creative skills to secure higher wages, and add value to their products.

Our creativity filter reveals the importance of innovative and organizational effort when working on innovation. This enables more creative behavior and thereby the smaller size of the filter. The filter is something to be taken into consideration by R\&D managers, as it correlates strongly with innovation output. As filter impedes the creative behavior of employees, it also constraints the development of new products. Thus, changes in organizational business strategy and R\&D support are important. Managers may find it useful to foster the learning activities of their employees through lean manufacturing, introducing a system of employee responsibilities, promoting the development of team work, the de-centralization of tasks, temporary job placements, and educational systems such as Sigma 6, Invest in People and other similar strategies. Developing team-building and rewarding the implementation of new ideas will perform some conduit of creativity functions. An open exchange of information via the organizational and managerial practices discussed is critical to innovation and the creativity-filter-innovation link.

Within these boundaries, R\&D and finance managers may encourage internal research and development in a number of ways, such as by financing it in-house or finding sponsors to fund creative work undertaken within the business. In particular, focus should be on the generation and implementation of new ideas employees both inside and outside of organization. To sum up, the creativity is a multilevel phenomenon, and managers should apply a systematic approach to institutionalized platforms as routines and practices inside their firm. Creativity filter is a conduit of creativity to innovation and it is about both innovation inputs and organizational practices (capabilities) that enables to commercialize creativity mix through recruitment of employees with various creative skills and experimenting to see what works best.

\section{Conclusion}

This study is the first to examine creativity filter as a conduit of creativity in innovative firms, demonstrating that creativity comes before knowledge and skills. Further integration of goal orientation theory, the knowledge spillover of entrepreneurship theory, organizational creativity theory and information exchange theory is needed to release the black box explaining the "creativity-innovation-productivity" links.

Policies targeting an increase local economic growth and tax revenues may focus on better commercialization of available creative skills at the firm level, and by providing support to new firm start-ups to spillover creativity. Developing a policy to 
support both extramural and intramural spillovers of creativity could increase innovation. Any increase in the gross value added in sales will accordingly affect the amount of corporate tax collected. To continue growing an entrepreneurial policy that supports both established firms and new businesses start-ups which employ individuals with creative skills at any level is important.

Government policies that enable businesses to implement new management techniques as well as major changes to their organizational structure while increasing their innovation should be further promoted. Having the creativity filter monitored by both shareholders and R\&D innovation teams in organizations may help to avoid possible failures in the development and impediment to novel ideas. To enhance radical innovation, our study suggests that innovation and skills policies should encourage the employment of individuals with software, multimedia, math, applied science and engineering skills. These skills could be easily transferred into innovation and profits.

Specifically, policies may focus on setting up a scheme that enables the development of R\&D teams at the firm level which are composed of both experienced entrepreneurs and individuals with a creative skills mix. The target of the creativity filter is to ensure that the gap between creativity and knowledge exchange is kept to a minimum and more ideas flow throughout the filter. In embedding the R\&D teams with entrepreneurs who can see opportunities and negotiate with "attentive-to-detail" members will intensify the knowledge flow. More start-ups may take place within the organization and benefit the productivity of established firms. The failure in doing so will increase the creativity filter size and increase the number of workers leaving and starting a new business.

\section{References}

1. Agarwal, R., Audretsch, D.B, Sarkar, M. 2010. Knowledge Spillovers and Strategic Entrepreneurship. Strategic Entrepreneurship Journal, 4: 271-283.

2. Amabile, T. M. 2000. Stimulate creativity by fueling passion. In E. Locke (Ed.), Handbook of principles of organizational behavior: 331-341. Malden, MA: Blackwell.

3. Audretsch, D. B., \& Lehmann, E. E. 2005. Does the knowledge spillover theory of entrepreneurship hold for regions?, Research Policy, 34(8): 1191-1202.

4. Audretsch, D.B. \& Keilbach, M.C. 2007. The Theory of Knowledge Spillover Entrepreneurship. Journal of Management Studies, 44: 1242-1254.

5. Audretsch, D. B., \& Belitski, M. 2013. The missing pillar: the creativity theory of knowledge spillover entrepreneurship. Small Business Economics, 41(4), 819-836.

6. Bilton, C. 2007. Management and creativity: From creative industries to creative management. London: Blackwell.

7. Collins, C. J., \& Smith, K. G. 2006. Knowledge exchange and combination: The role of human resource practices in the performance of high-technology firms. Academy of Management Journal, 49: 544-560.

8. Cummings, A., \& Oldham, G. 1997. Enhancing creativity: Managing work contexts for the high potential employee. California Management Review, 40(1): 22-38.

9. Dirks, K. T., \& Ferrin, D. L. 2001. The role of trust in organizational settings. Organization Science, 12: 450-467. 
10. Florida, R.L. 2002. The rise of the creative class. New York: Basic Books.

11. George, J. M., \& Zhou, J. 2007. Dual tuning in a supportive context: Joint contributions of positive mood, negative mood, and supervisory behaviors to employee creativity. Academy of Management Journal, 50: 605-622.

12. Gong, Y., Kim, T. Y., Zhu, J. \& Lee, D. R. 2013. A Multilevel Model of Team Goal Orientation, Information Exchange, and Creativity. Academy of Management Journal, 56: 827-851.

13. Hirst, G., van Knippenberg, D., \& Zhou, J. 2009. A crosslevel perspective on employee creativity: Goal orientation, team learning behavior, and individual creativity. Academy of Management Journal, 52: 280-293.

14. Levitt, T. 2002. Creativity is not enough. Harvard Business Review, 80(8): 137-144.

15. Lovelace, K., Shapiro, D. L., \& Weingart, L. R. 2001. Maximizing cross-functional new products teams' innovativeness and constraints adherence: A conflict communications perspective. Academy of Management Journal, 44: 779-793.

16. Miron, E., Erez, M., \& Naveh, E. 2004. Do personal characteristics and cultural values that promote innovation, quality, and efficiency compete or complement each other? Journal of Organizational Behavior, 25: 175-199.

17. Miron-Spektor, E., Erez, M., \& Naveh, E. 2011. The effect of the conformist and attentiveto-detail members on team innovation: reconciling the innovation paradox. Academy of Management Journal, 54(4): 740-760.

18. Oldham, G. R. \& Cummings, A. 1996. Employee creativity: Personal and contextual factors at work. Academy of Management Journal, 39: 607-634.

19. Taggar, S. 2002. Individual creativity and group ability to utilize individual creative resources: A multilevel model. Academy of Management Journal, 45: 315-330.

20. Shalley, C. E., Zhou, J., \& Oldham, G. R. 2004. The effects of personal and contextual characteristics on creativity: Where should we go from here? Journal of Management, 30 : 933-958.

21. Shalley, C. E., Gilson, L. L. \& Blum, T. C. 2009. Interactive effects of growth need strength, work context, and job complexity on self-reported creative performance. Academy of Management Journal, 52: 489-505.

22. Taylor, A., \& Greve, H. R. 2006. Superman or the fantastic four? Knowledge combination and experience in innovation teams. Academy of Management Journal, 49: 723-740.

23. Tierney, P., \& Farmer, S. M. 2002. Creative self-efficacy: Potential antecedents and relationship to creative performance in two organizational settings. Academy of Management Journal, 45: 1137-1148.

24. Tsai, W., \& Ghoshal, S. 1998. Social capital and value creation: The role of intrafirm networks. Academy of Management Journal, 41: 464- 476.

25. West, M. A. 2002. Sparkling fountains or stagnant ponds: An integrative model of creativity and innovation implementation in work groups. Applied Psychology: An International Review, 51: 355-386.

26. West, M. A., \& Anderson, N. R. 1996. Innovation in top management teams. Journal of Applied Psychology, 81: 680-693. 